\title{
Action Research into a Flood Resilient Value Chain - Biochar-based Organic Fertilizer Replaces Chemical Fertilizer with Double Yield of Pea in Udayapur, Nepal
}

\author{
Anu Joshi Shrestha ${ }^{1, ~ *}$, Bishnu Hari Pandit ${ }^{2}$ \\ ${ }^{1}$ Livelihood Department, International Centre for Integrated Mountain Development, Lalitpur, Nepal \\ ${ }^{2}$ Department of Watershed, Kathmandu Forestry College (KAFCOL), Kathmandu, Nepal
}

Email address:

anu.shrestha@icimod.org (A. J. Shrestha), bhpandit29@gmail.com (B. H. Pandit)

${ }^{*}$ Corresponding author

\section{To cite this article:}

Anu Joshi Shrestha, Bishnu Hari Pandit. Action Research into a Flood Resilient Value Chain - Biochar-based Organic Fertilizer Replaces Chemical Fertilizer with Double Yield of Pea in Udayapur, Nepal. American Journal of Agriculture and Forestry.

Vol. 5, No. 4, 2017, pp. 84-93. doi: 10.11648/j.ajaf.20170504.12

Received: May 4, 2017; Accepted: May 5, 2017; Published: June 9, 2017

\begin{abstract}
This paper describes the results of an action research project to identify and analyze a flood resilient value chain option for families of migrant workers in flood affected areas in six Village Development Committees (VDCs) in Udayapur district in Nepal. The best option was cultivation of green peas, with crop productivity increased using urine-biochar prepared on farm as an organic fertilizer and soil improver. The paper describes the value chain selection process and comparison of the effects of different fertilizers on vegetable crops. The yield of fresh pea pods from plots treated with urine-biochar plus Farm Yard Manure (FYM) was more than twice that with Nitrogen Phosphorus Potash (NPK) only, and close to three times that with FYM only (farmers' control). The yields of a range of vegetables increased markedly in plots treated with urine-biochar. Analysis of the value chain indicated that farmers would benefit most by marketing to large buyers or direct to supermarkets in the capital through a farmers' association. Suggestions are made for future actions both country-wide (promotion of biocharbased organic fertilizer as a priority) and locally (strengthening the pea value chain).
\end{abstract}

Keywords: Biochar-based Organic Fertilizer, Chemical Fertilizer, Flood Resilient Value Chain, Fresh Green Pea, Migrant Workers' Families, Yield

\section{Introduction}

There is a significant gap between current and potential agricultural production in Nepal. The low levels of productivity are the result of several factors including a high level of subsistence farming, low level of access to and adoption of suitable improved technologies (both on farm and post-harvest), poor availability of inputs (planting material, improved breeds, fertilizer, feed, plant and animal health protection, irrigation, electricity, finance), and limited investment in the agricultural sector [1].

One of the major problems in Nepal is that farmers have poor access to chemical fertilizers. In 2012, only $28.4 \mathrm{~kg}$ plant nutrients were applied per hectare of arable land, which is very low even by South Asian standards [2]. Nepal imports all of its chemical fertilizers but the supply is not sufficient to meet the demand. The fertilizer supply problem is occasionally further aggravated by unofficial blockades and strikes. Although the country has a fertilizer subsidy policy. The Ministry of Agriculture Development (MOAD) subsidized fertilizer forms only a tiny fraction of the total fertilizer supply [1]. The remainder is supplied through uncontrolled informal channels, facilitated by the open and porous border with India to the south. Thus, as with other inputs, the quality of the supply is also a serious issue. Application of poor quality fertilizer results in lower than anticipated impacts on crop productivity and profitability [2, 3]. The imported fertilizers are expensive and prices are rising, which further limits access, especially for poor farmers. Finally, even where the supply and quality of fertilizer is sufficient, application tends to create 
environmental and soil acidity problems [4].

The problem is not only one of low productivity and poor input supply. Both the input and the output markets are poorly integrated. Farmers, especially smallholders, not only lack access to quality inputs, the link to the markets for their products is also weak due to lack of infrastructure such as farm-to-market roads, collection centers and storage facilities, and poor access to information about markets and prices. The problems of market access and farmers being able to achieve a fair return from their produce can be addressed using a value chain approach to identify the most suitable crops for a specific situation and the leverage points for increasing return to producers $[5,6]$.

Low productivity can then be addressed using innovative approaches to inputs. A number of the problems are associated with fertilizer access, and use can be overcome through use of biochar - a type of fine-grained charcoal created by burning wood and agricultural byproducts slowly, at low temperatures, with a reduced oxygen supply - in combination with locally available fertilizer products [7]. Treatment with biochar combined with compost or manure has been shown to be effective in restoring severely depleted soils $[8,9]$. A combined fertilizer and soil improvement product can be prepared from cow urine and biochar and, used in combination with legume crop farming, can be an important tool for increasing food security and cropland diversity in areas with severely depleted soils, scarce organic resources, inadequate water for irrigation, and limited supplies of chemical fertilizer $[9,10]$. This type of sustainable technology using locally available products is highly relevant for smallholder farmers in a country like Nepal.

An action research project to identify and analyze the most feasible flood resilient value chain option integrating economic and environmental integrity was carried out in six village development committee (VDC) areas in Udayapur district in Nepal. Udayapur is regularly affected by floods during the monsoon period. Many smallholder farmers migrate for work, either seasonally or for longer periods, as a means of coping with the economic challenges resulting from floods. The families of the migrant workers that are left behind are often headed by women who face the difficulties of carrying out both farm and household work and cultivating the small plots of land in flood prone areas to provide a supplementary subsistence income. The project focused on these families, and identifying a promising value chain and ways to upgrade it to ensure they received the best returns. The paper describes the flood resilient value chain selection process and comparison of the effects of biochar based organic fertilizer and chemical fertilizer on vegetable crops, especially green peas. Finally, suggestions are made for the future actions both locally and country-wide.

\section{Methods}

The research was carried out between November 2015 and May 2016 together with the Nepal Institute for Development Studies (NIDS) and migrant workers' families in six village development committee areas (VDCs) in Udayapur District Hadiya, Jogidaha, Sunderpur, Tapeswori, Thoksila (formerly Rampur), and Risku (Figure 1). These VDCs were selected as they are vulnerable to floods from the Koshi River and the majority of households cultivate vegetables. The communities are poor and their economic development is a priority for the government.

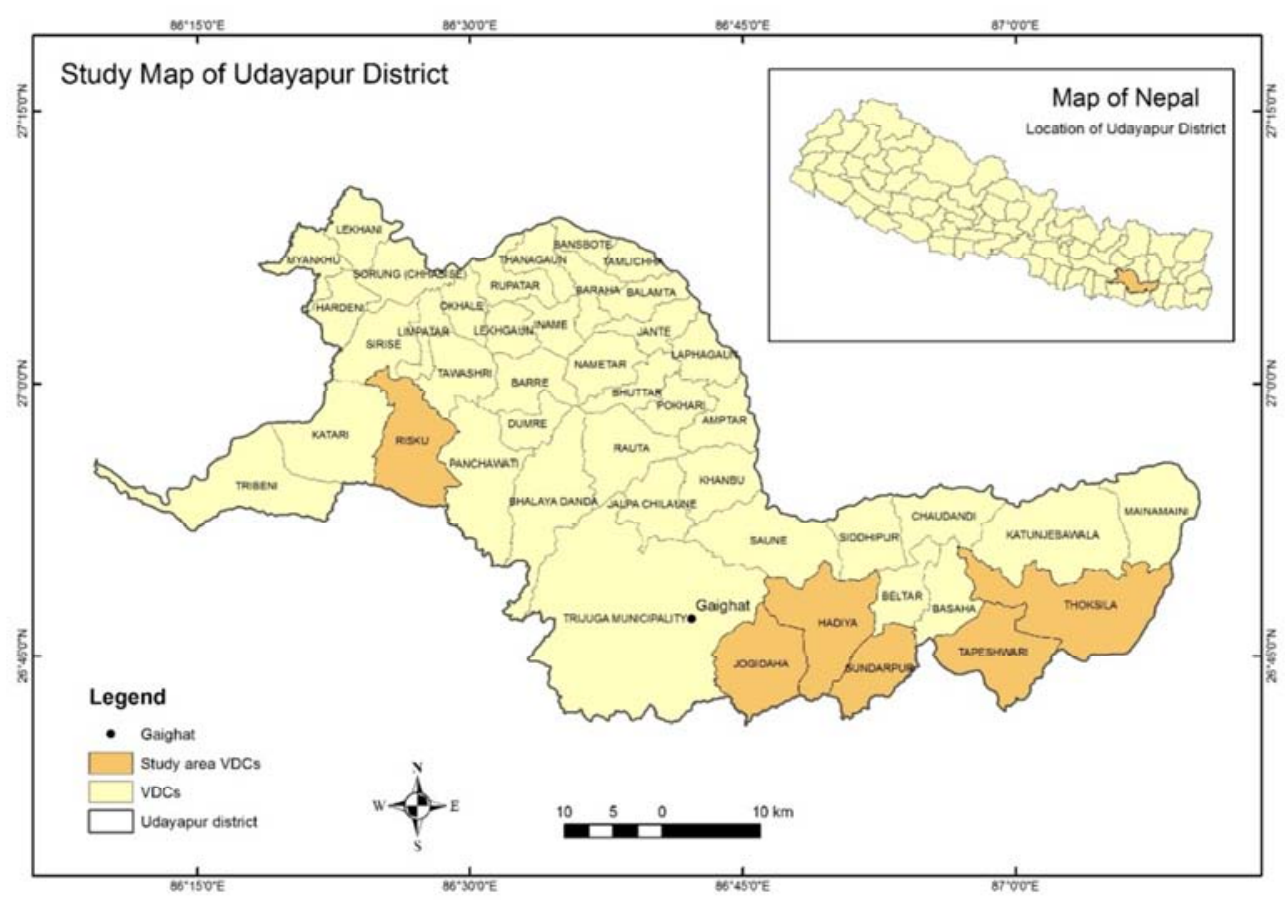

Figure 1. The study area. 


\subsection{Action Research Approach and Value Chain Analysis}

The action research methodology was chosen as it is designed to integrate economic, environmental, and social factors in the value chain analysis, while emphasizing strategic and political approaches to ensuring sustained improvements for disadvantaged groups [11]. Action research takes place in real-world situations and is aimed at solving specific problems involving the target group and stakeholders as co-researchers [11].

\subsection{Selection of Best Option Value Chain}

Preliminary information on the most important value chains for the farmers in the district was gathered from a literature review and meetings with key stakeholders including representatives from the District Agriculture Development Office (DADO), District Cooperative Office (DCO), National Institute for Development Studies (NIDS), traders and farmers in the VDCs, and Non-Government Organizations (NGOs) working on vegetable farming in Nepal. Six promising flood resilient value chain options were selected: green peas and beans, goat, chicken and duck, piggery/fishery, milk plus bullock power, and moringa leaf and pods. A commodity matrix ranking approach was used to identify the most promising option $[6,12]$. The value chains were evaluated in focus group discussions using seven criteria: market and market demand, economy of scale and outreach, high value flood resistant variety, stakeholders' interest and commitment (women and migrant' workers households), coordination, short turnover, and leverage. Each criterion was given a score from 1 to 5 , with 5 representing maximum compliance and 1 minimum compliance. Overall ranking was determined using a weighted average of the seven criteria. Table 1 shows the results of the assessment. Green peas and beans were the most favored option with a score of 4.2 , and of these, green peas were clearly preferred by most farmers. Moringa was mainly planted by farmers in Sundarpur and Tapeswori which are relatively far from the market; the crop had provided little benefit and had the lowest rating. The pea value chain was selected for the action research trials.

Table 1. Selection of value chain diversification options.

\begin{tabular}{|c|c|c|c|c|c|c|c|}
\hline \multirow[b]{2}{*}{ Criterion } & \multirow{2}{*}{$\begin{array}{l}\text { Weighting } \\
\text { (\%) }\end{array}$} & \multicolumn{6}{|c|}{ Value chain } \\
\hline & & Goat & $\begin{array}{l}\text { Milk and } \\
\text { bullock power }\end{array}$ & $\begin{array}{l}\text { Peas and } \\
\text { beans }\end{array}$ & $\begin{array}{l}\text { Piggery or } \\
\text { fishery }\end{array}$ & $\begin{array}{l}\text { Chicken and } \\
\text { ducks }\end{array}$ & Moringa \\
\hline Markets and market demand & 20 & 0.87 & 0.67 & 0.87 & 0.67 & 0.53 & 0.40 \\
\hline Economy of scale and outreach & 15 & 0.70 & 0.35 & 0.65 & 0.30 & 0.50 & 0.35 \\
\hline High value flood resilient variety & 15 & 0.35 & 0.30 & 0.65 & 0.40 & 0.45 & 0.40 \\
\hline Stakeholders' commitment & 15 & 0.60 & 0.35 & 0.55 & 0.50 & 0.40 & 0.30 \\
\hline Short turnover (returns within six months) & 15 & 0.45 & 0.25 & 0.70 & 0.35 & 0.45 & 0.30 \\
\hline Coordination & 10 & 0.37 & 0.20 & 0.40 & 0.23 & 0.30 & 0.20 \\
\hline Leverage & 10 & 0.37 & 0.13 & 0.37 & 0.27 & 0.33 & 0.13 \\
\hline Total & 100 & 3.7 & 2.3 & 4.2 & 2.7 & 3.0 & 2.1 \\
\hline
\end{tabular}

\subsection{Analysis of the Green Pea Value Chain}

Three broad categories of stakeholders have a role in facilitating the value chain functions and processes: (1) the upstream actors, i.e. the vegetable growers, especially migrant workers' families; (2) the downstream actors, i.e. village and district traders; these are powerful actors as they have linkages with end markets in Nepal and India and influence the prices and terms of trade; and (3) facilitators, including the government, who are responsible for regulating and implementing agricultural policies, and NGOs, who facilitate the participation of farmers in value chains by mobilizing them, providing information, and organizing training. Detailed information on the value chain such as production, markets, costs, profit margins, and problems and opportunities was obtained from all three groups.

For the upstream actors, a list of households in two wards in Tapeswori VDC and one ward in each of the other five VDCs was obtained from the NIDS office. The seven wards have 328 households, out of a total of approximately 7,000 in the six VDCs. The number of migrant workers, and thus of migrant worker' households, fluctuates a little seasonally as well as in response to external events. A total of 240 migrant worker households were identified in the seven wards (200 in the initial phase of research and a further 40 later); 114 of these $(47.5 \%)$ were selected at random for the research. Baseline information on the farmers' practices in pea growing and any income from peas was collected in face-toface interviews using a close-ended questionnaire in December 2015. Most of the households cultivated some peas but only four grew beans, confirming the choice of the pea value chain for the trials.

Six focus-group discussions (one per VDC) were organized with the downstream actors and facilitators to understand the functioning of the vegetable value chain in general and the pea value chain in particular.

Information from facilitators was obtained during the meetings with representatives of the various organizations on all the value chains (see above).

\subsection{Pea and Biochar Action Research Trials}

One of the important leverage points in the value chain was to increase crop productivity so that farmers would have a greater volume to sell from the small plots available. Biochar with organic fertilizer was investigated as an appropriate, low cost, and locally sustainable method of soil 
improvement.

\section{Biochar production}

Project staff (the principal investigator and NIDS field staff) carried out hands-on training events on producing biochar in a Kon-Tiki soil pit kiln at all six sites in November 2015 with participants from all 114 selected families.

The Kon-Tiki soil pit kiln method, also known as flame curtain pyrolysis, was introduced in 2014 as a simple and inexpensive way for small farmers to produce high quality biochar in bulk, avoiding both the emissions associated with other methods and the high costs of modern technological approaches [13, 14]. The method is being distributed as an open source technology [14] by the Ithaka Institute (www.ithaka-institut.org). Essentially it consists of heating biomass layer by layer in a conically formed soil pit kiln 1.5 $\mathrm{m}$ in diameter at the top and $0.75 \mathrm{~m}$ deep in such a way that the powerful flames from each fresh layer provide a 'curtain' which excludes oxygen from the pyrolyzing mass below. Initially, a small amount of fast burning biomass is fired to reach a high temperature; further thin layers of biomass are added as soon as ash starts to appear on the top surface. The manual layering is repeated until the soil pit is filled at which point the pyrolysis process is ended by quenching with water. Biochar produced in this way is of very high quality, while emission of greenhouse gases and other toxic substances is very low. The biochar yield generally lies between 15 and $30 \%$ of the original feedstock on a dry matter base. In Udayapur, we mainly used Eupatorium species (an invasive forest shrub known in Nepal as 'forest killer') as feedstock, together with some leftover animal waste material. The cooled biochar was mixed with urine collected from stall fed cattle in the ratio 10 liters of urine to $1 \mathrm{~kg}$ biochar.

\section{Selection of VDCs for the field trials}

The potential for introducing pea cultivation as a flood resistant livelihood option was assessed in the six VDCs based on the present status of pea growing and farmers' interest. Before the project, close to $70 \%$ of farmers were growing peas for home consumption in a mixed or intercropping system with major crops such as rice and maize, and sometimes with other vegetable crops, but only a few were growing pea for sale in pure stands, generally as a winter crop using irrigation and residual moisture. These farmers were mostly in Hadiya and Jogidaha VDCs, which lie closer to the district capital Gaighat. Some NGOs had promoted growing of peas and beans in Sundarpur among very poor farmers who have access to suitable land but cannot afford the inputs needed to grow other crops (cabbage, cauliflower). However, compared to other crops, there are generally few promotion activities targeting pea production and marketing.

Only a few of the farmers in Hadiya and Jogidaha used improved seeds, which were mostly obtained from research institution experiments or through District Agriculture Development Office subsidy programs. Use of improved seeds also depended on the level of education among farmers. The seeds are very expensive to buy with $1 \mathrm{~kg}$ costing around NPR 7,000 (USD 65). Most farmers used their own seed in subsequent years. Where farmers are well organized, they sometimes acquired some seeds on loan, which they repay in kind to their associations.

Table 2 shows the ranking of VDCs in order of preference for pea promotion.

Table 2. Priority ranking of VDCs for growing peas.

\begin{tabular}{|c|c|c|}
\hline VDC & Rank & Reasons for rank \\
\hline Hadiya & 1 & $\begin{array}{l}\text { Traditional part of the farming system, available } \\
\text { land, good soils, cash culture already present, } \\
\text { motivated women's group promoting pea value } \\
\text { chain, close to } 50 \% \text { of families already growing } \\
\text { peas on a very small scale }\end{array}$ \\
\hline Jogidaha & 2 & $\begin{array}{l}\text { Available land, proximity to key market (Gaighat), } \\
\text { many organizations promoting activities (MEDEP, } \\
\text { cooperatives), scope to grow peas as seeds, peas } \\
\text { traditional to region due to good soils and good } \\
\text { climate }\end{array}$ \\
\hline Sundarpur & 3 & $\begin{array}{l}\text { Dry area, sandy soils, distant from markets, peas } \\
\text { and beans only grown by a few farmers, active } \\
\text { women's group growing peas and beans }\end{array}$ \\
\hline Tapeswor & 4 & $\begin{array}{l}\text { Small landholdings with many competing crops } \\
\text { grown mostly for food and priority given to other } \\
\text { crops, poor transport, few promoters, very wet land }\end{array}$ \\
\hline $\begin{array}{l}\text { Rampur } \\
\text { Thoksila }\end{array}$ & 5 & $\begin{array}{l}\text { Poor transport, distant from markets, few promoters, } \\
\text { rainfed, irrigation priority given to tomato }\end{array}$ \\
\hline Risku & 6 & $\begin{array}{l}\text { Far from district headquarters and markets, many } \\
\text { other competing crops, farmers focus on goats as a } \\
\text { livelihood strategy as the settlement has forest } \\
\text { attached }\end{array}$ \\
\hline
\end{tabular}

Source: Field survey 2015

Farmers in the 114 selected households were asked about their interest in taking part in the field trials and the amount of land they could commit. More than half (62 of 114) expressed interested in growing peas in the 2015/16 winter season using biochar. Hadiya and Jogidaha VDCs were selected for the field trials on the basis of the priority ranking and farmers' commitment.

Field trials

Pea seed was provided to all 28 committed farmers in Hadiya and Jogidaha. Most of these farmers carried out empirical trials using urine-biochar as a soil treatment. Four farmers in Hadiya carried out scientific trials with pea. The trials were carried out in $10 \mathrm{~m}^{2}$ plots with five repetitions of each. Three different treatments were used per plot of $10 \mathrm{~m}^{2}$ : A) 10 liters urine $+1 \mathrm{~kg}$ biochar $(1 \mathrm{~kg}$ dried biochar from Eupatorium and rice straw has a volume of approx. 10 liters) + 10 kg FYM; B) 60 g N $_{2} \mathrm{O}+80$ g $_{2} \mathrm{O}_{5}+60$ g K $2 \mathrm{O}$; C) 10 $\mathrm{kg}$ FYM (farmer's practice). Peas were planted at $25 \mathrm{~cm}$ intervals in rows $1 \mathrm{~m}$ apart in late November 2015 and harvested from February to March 2016.

Three farmers in Jogidaha carried out scientific trials with other vegetables (bottle gourd, cauliflower, and tomato) using treatments $\mathrm{A}$ and $\mathrm{C}$. The planting scheme is given in the results section. All farmers in the selected households in the seven wards were trained in urine-biochar production and carried out empirical trials using urine-biochar treatment with their normal winter crops. 


\section{Results and Discussion}

\subsection{The Green Pea Value Chain}

Green (garden) peas (Pisum sativum 1) are used as a cash crop in many parts of Nepal and their potential to contribute to the national economy and to generate income for farm families in flood vulnerable areas has been well recognized in recent years. They mature earlier than other crops and can provide a bridging income before the rainy (monsoon) season - and before flooding occurs. The crop is cultivated both for the tender and immature peas, which are used as a vegetable or in soup, and for the mature dried peas, which can be stored and used as a pulse, as well as providing seed. Peas are highly nutritious, they have a high content of digestible protein $(7.2 \mathrm{~g} / 100 \mathrm{~g})$, carbohydrate $(15.8 \mathrm{~g})$, vitamin C (9 mg), phosphorus (139 mg), and minerals [15]. Fresh peas can be preserved in canned, frozen, or dehydrated form for use during the off-season, including at times of flood [16].

Peas as a crop have the added advantage that as legumes they can add nitrogen to the soil and reduce the amount of fertilizer required by the follow-on crop. The soil enriching and conditioning properties mean that pea is an integral component of sustainable agriculture. Farmers in the study villages reported that when maize is planted after legumes, the yield is better and less fertilizer is needed for the maize. The farmers also practiced intercropping with maize, potato, and wheat crops and along the boundary of cole crops (cabbage and cauliflower), especially where farmland is limited. Peas thus provide a self-sustaining system as they sustain soil fertility and use less water (making use of residual moisture during the winter season and a small amount of irrigation at other times), which fits well with efforts to counter the negative effects of climate change and floods. Peas can be promoted as a soil fertility improvement initiative in the flood victim areas.

Peas can be grown in two seasons in the study village area: the main one post-monsoon from late September to December, and the second from December to February/March. Peas can only be grown from April to September in hill areas, where it is cooler and flooding less extensive. Peas are sown by broadcasting or dibbling at a depth of $2.5-5.0 \mathrm{~cm}$ and spacing of $50 \times 25 \mathrm{~cm}(50-60 \mathrm{~kg} \mathrm{seed} / \mathrm{ha})$ in flat or raised beds surrounded by bunds. The yield is higher in the September sown crop; the temperature increases from early March onwards which hastens the maturity and reduces the yield; pea quality is also lower due to the conversion of sugars to hemicellulose and starch at higher temperatures. However, although the yield of January sown crops is lower, the fresh peas fetch a higher price [17].
Peas can be marketed as fresh pods or mature dry peas (to use as seeds or pulses). In some areas in Nepal, peas are grown as an additional source of income (secondary to others such as cereals and sugarcane), while in others they are considered a high-income crop, better than maize, especially when production is high. The total production of peas in Nepal in 2014 was 19,383 tonnes and market demand is rising. There is a potential to increase income by harnessing urban city markets [17]. The key challenges to realizing the potential of peas to contribute to farm income include the lack of storage for longer periods post-harvest and the need for immediate sale for cash to meet regular needs; poor information about markets; lack of structured markets; planting of multiple crops on a single plot; and lack of access to quality seed.

As with most vegetables, green pea cultivation is highly labor intensive and requires high application of manure and fertilizer [18]. The biggest cost is for manure and fertilizer, followed by draft (bullock) power and human labor, and pesticides and other chemicals. Thus reducing the cost of fertilizer is a very promising approach for upgrading the chain, which can be done by urine biochar fertilizer as used in maize [19].

\subsection{Pea and Biochar Action Research Trials}

\section{Biochar and pea}

The action research investigated replacing costly chemical fertilizer with locally produced organic urine-biochar fertilizer. The results of the trials growing peas with different types of soil treatment are summarized in Table 3 . The yield (fresh pea pods) from plots treated with urine-biochar plus FYM was $221 \%(p<0.01)$ of yield with NPK only, and $292 \%(p<0.001)$ of yield with FYM only (farmers' control). The yield differences were similar in all four plots although the overall yields differed slightly among farmers. The increase in production using biochar is in line with results observed by other authors for many other crops e.g. [2, 20, 21]. The difference in pea crop yield between NPK and FYM only treatment was not significant, which indicates that substituting chemical fertilizer for FYM would not lead to a meaningful increase in yield.

All 24 farmers who carried out empirical tests using urinebiochar with the supplied pea seed reported similarly positive results with much higher yields than they would normally expect.

Table 3. Yields in farmers' pea trials with urine-biochar and other treatments.

\begin{tabular}{|c|c|c|c|c|c|c|}
\hline \multirow{2}{*}{ Farmer } & \multicolumn{3}{|l|}{ Yield in gm/plot } & \multicolumn{3}{|c|}{ Treatment difference (\%) } \\
\hline & A. Urine/biochar/FYM & B. NPK & C. FYM & $A$ and $B * *$ & $A$ and $C^{* * *}$ & $B$ and $C^{*}$ \\
\hline Nira Thapa & 7,132 & 3,718 & 2,562 & 192 & 280 & 146 \\
\hline Januka Poudel & 6,601 & 2,674 & 2,699 & 256 & 248 & 99 \\
\hline Mandira Thapa & 7,226 & 2,975 & 2,145 & 243 & 352 & 144 \\
\hline Dhan Maya Banjara & 9,312 & 4,846 & 3,236 & 193 & 288 & 150 \\
\hline Total & 7,568 & 3,553 & 2,660 & 221 & 292 & 135 \\
\hline
\end{tabular}

$\mathrm{A}=1 \mathrm{~kg}$ urine $+1 \mathrm{~kg}$ biochar $+10 \mathrm{~kg}$ FYM per plot

$\mathrm{B}=60 \mathrm{~g} \mathrm{~N}_{2} \mathrm{O}+80 \mathrm{~g} \mathrm{P}_{2} \mathrm{O}_{5}+60 \mathrm{~g} \mathrm{~K}_{2} \mathrm{O}$ per plot

$\mathrm{C}=10 \mathrm{~kg}$ FYM per plot (farmer's practice)

Paired t-test $* \mathrm{p}<0.01, * * \mathrm{p}<0.001, * * * \mathrm{p}<0.001$ 
The comparative results of the trials were unequivocal. However, it is likely that the total yields for all treatments would have been higher if the farmers could have made use of the best growing conditions by planting in September. For logistical reasons, the trials started in late November with the main harvest in March, which is a lower yielding season.

Other vegetable crops

The results of the trials growing other vegetables with and without urine-biochar are summarized in Table 4. As with pea, the yield from plots treated with urine-biochar was markedly higher (from 170 to $200 \%$ ) than the yield from untreated plots. The yield of bottle gourd in the biochar plot was equivalent to $90 \mathrm{t} / \mathrm{ha}$, which is consistent with the results obtained for pumpkin with biochar application elsewhere in Dhading district (82 t/ha) [2]. In the interviews, farmers indicated a high motivation for using urine-biochar in other vegetable crops; one had already produced more than $1 \mathrm{t}$ of biochar to use for her summer crops.

The farmers in the other VDCs who tested urine-biochar application with their regular crops reported similar increases in production. The results have led to considerable interest in urine-biochar application. The project coordinator noted that close to 200 flood-affected farmers in the project VDCs had started investing in the pea value chain using urine-biochar by fall/winter $2016(\mathrm{Mr}$ Ram Basnet, personal communication).

Table 4. Yields in farmers' trials of other vegetables with and without biochar treatment.

\begin{tabular}{llllll}
\hline \multirow{2}{*}{ Crop } & Farmer & Plot size & $\begin{array}{l}\text { No. of plants per } \\
\text { plot }\end{array}$ & \multicolumn{2}{l}{ Yield (kg) } \\
\cline { 3 - 6 } & & 2 & Urine/biochar/FYM & FYM only & Difference (\%) \\
\hline Bottle gourd & Mahakali Chaudhari & $10 \mathrm{~m}^{2}$ & 60 & 205 \\
Cauliflower & Devi Khadka & $10 \mathrm{~m}^{2}$ & 6 & 18 & 10 \\
Tomato & Bhagabati Khatri & $10 \mathrm{~m}^{2}$ & 6 & 15 & 9 \\
\hline
\end{tabular}

Source: Farmers' records

\subsection{Actors and Value Chain Mapping}

The value chain for pea grown in Udayapur district was analyzed in order to identify different options and leverage points to increase the income for growers. Up to 2014/15, the farmers in the six VDCs produced around $37 \mathrm{t}$ of peas annually, but only $4 \mathrm{t}$ was sold. The demand is high, the biggest wholesale trader at Gaighat can take $2 \mathrm{t}$ of fresh pods per day during the main harvest season; at present this demand is met from Siraha and Sunsari districts as well as other parts of Udayapur. The results of the value chain analysis are shown in Figure 2. The values are based on an estimated production of $175 \mathrm{t}$ annually (main harvest) from the six VDCs, based on the amount of land they could use to grow pea and the expected yield using urine-biochar. The absolute values are estimates, but the comparative values of the different pathways are based on known prices.

A large number of intermediaries are involved in the movement of vegetable produce from producer to consumer; they retain a large proportion of the final sale price and the share returned to the producer is very low. If ways can be found to reduce the number of intermediaries by marketing both fresh green peas and mature pea seeds to new supply chains involving large-sized buyers (for example in Mugling and Dumre), the market margin would be higher. This type of marketing model improves marketing efficiency through vertical integration and coordination and gives a higher price to the producers. Figure 2 shows the potential benefit of marketing to large buyers rather than village traders, with a tripling of the marketing margin for farmers (to 33\% from $10 \%$ ). Direct sale to local (district) consumers also increases profitability providing a marketing margin of $39 \%$. The highest marketing margin of $44 \%$ would be obtained from direct marketing of fresh green peas to department stores and supermarkets (such as Bhat Bhateni) in Kathmandu (strand
III).

The farmer's margin when selling to village traders is $10 \%$ for fresh green pods, $29 \%$ for seeds, and a negative return for dry peas. However, if green peas are packed or canned, the prices would triple (to at least NPR $180 / \mathrm{kg}$ ). This would be less complicated than selling seeds, which entails considerable administrative costs for certification.

There are many other key actors involved in marketing of peas in Nepal. At the national level, there are agro-vet and seed marketing cooperatives and companies such as the Nepal Agroforestry Seed Cooperative Limited (NAFSCOL), and Nepal Agroforestry (NAF) Seed Company and Agriculture Marketing Division. At the district level, there are district cooperatives, district small cottage industry offices, and district agriculture development offices as well as private agro-vet dealers and traders, private agri-business companies, and municipal marketing centers. At the local level, there are many small farmers' associations (cooperatives) such as the NGOs Center for Environmental and Agricultural Policy Research, Extension and Development (CEAPRED), Local Development Forum Nepal, Women Rights Activists (WORAC), and NIDS; the Suva Laxmi Cooperative in Hadiya and Sundarpur deals specifically with pea and vegetable marketing. The United Nations Development Program's Micro-Enterprise Development Program (UNDP MEDEP) is also keen to support farmers in micro enterprise development. In the planned pea business plan training, these agencies and projects can be invited for discussion on ways to ensure synergy. Agro-vet centers are expected to supply affordable seeds in the first year, at present cost of seeds is one of the factors preventing farmers from taking up the pea value chain. From the second year onwards, the farmers' federation will be able to produce its own seeds. One farmer in the trials had already reserved mature peas as seed for planting in the 
next season in order not to be dependent on outsiders for seed.

A large part of pea and vegetable marketing is through local vendors to household consumers. A system of vendors around the country is used by buyers to source products and by farmers to sell them. Vendors go from door to door in search of peas and are the primary market outlet for most farmers. Most green pea pods are bagged in gunny bags by farmers and then stored by vendors in bulk in warehouses. The weight of bags depends on the buyer but $50 \mathrm{~kg}$ is common. Grading is rarely used other than ensuring that peas are of a single type rather than being mixed. The price depends on the type of vendor and season.

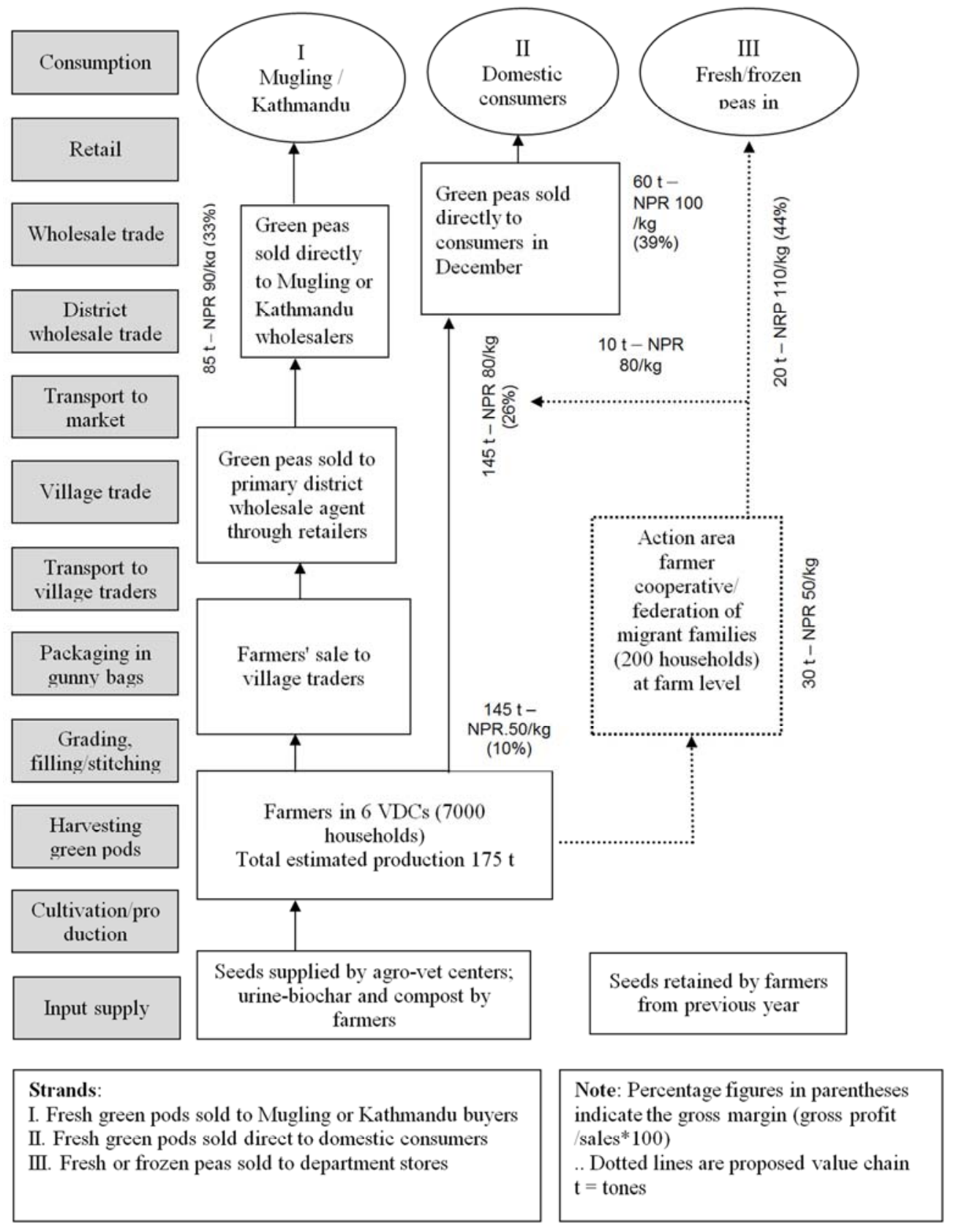

Figure 2. Fresh green pea value chain map for Udayapur, Nepal.

Gaighat Municipality provides space for direct marketing of farmers' produce; farmers can hire a $2.5 \times 2.5 \mathrm{~m}$ area for selling for NPR 50-100 per day. NIDS, LDFN, and CEAPRED facilitate the formation of cooperatives, while farmer associations such as Subha Laxmi and the Small Farmers associations in Jogidaha, Hadiya, and Sundarpur are more interested in ensuring that farmers receive a good price.
The District Agriculture Development Office at Gaighat has agronomists and horticulturists to support farmers in growing of peas and marketing.

There are seasonal variations in the quantities traded related to the cropping season and harvest of peas. Peas are mostly grown in winter and the crop is rainfed. Across Nepal, prices are highest from September to December before the 
main harvest, and lowest from April to mid-June. Prices drop during the harvest season but farmers still sell rather than storing both because they need immediate cash to cover their needs and because they fear post-harvest losses. Farmers do not even store for their own consumption, preferring to sell and buy for later consumption from others.

Farmer-based associations need to empower farmers to sign contracts with producers in the form of purchase agreements (specifying the quality of peas required) after signing agreements with an identified buyer.

\subsection{Financing}

Most farmers finance their own planting activities from the money they receive from sales. However, some have access to bank credit and/or special project financing, especially important when they transport and deliver their produce themselves, and some can use remittances. When banks finance, farmers must repay their loans on time which can pose problems.

Farmers are sometimes financed by loans from village cooperatives. There were two village cooperatives in the pilot VDCs (Subha Laxmi and Small Farmers) both with considerable savings available for investment. The 240 migrant workers families in the six project areas started pooling their savings during the project and deposited these funds in the cooperatives ready for investment in the next phase.

The amount of disposable income available to the families of migrant workers from remittances and other sources is shown in Table 5. The amount varies considerably. Approximately $38 \%$ of those interviewed (43 households) had an annual income greater than NPR 200,000 (USD 1,870 ) while $14 \%$ had an annual income of less than NPR 50,000 (USD 467). Clearly growing pea using urine-biochar has considerable potential to improve the income of these families if the crop can be properly marketed. Notwithstanding the disparity in income, almost all families expressed their willingness to invest in value chain development activities at a meeting held to discuss introducing the pea value chain with biochar as a means of generating income.

Table 5. Disposable income of families of migrant workers (mainly from remittances).

\begin{tabular}{llllll}
\hline VDC & Well off & Medium & Poor & Ultra poor & Total \\
\hline Hadiya & 10 & 5 & 3 & 3 & 21 \\
Jogidaha & 8 & 9 & 7 & 2 & 26 \\
Sundarpur & 11 & 4 & 4 & 2 & 21 \\
Tapeswori & 3 & 4 & 5 & 3 & 15 \\
Rampur & 6 & 4 & 5 & 4 & 19 \\
Risku & 5 & 3 & 2 & 2 & 12 \\
Total & 43 & 29 & 26 & 16 & 114 \\
\hline
\end{tabular}

Well-off $=$ annual household income above NPR 200,000 (USD 1,870)

Medium $=$ annual household income from NPR 100,000 (USD 935) to 200,000 (USD 1,870)

Poor $=$ annual household income from NPR 50,000 (USD 467) to 100,000 (USD 935)

Ultra-poor $=$ annual household income less than NPR 50,000 (USD 467)

\section{Conclusions}

Sustainable farming technologies are becoming increasingly relevant for farmers with depleted soils, especially smallholder farmers, given the poorly integrated input markets and lack of access to affordable quality fertilizer and other inputs. The imported chemical fertilizers are expensive and prices are rising; urine biochar offers a cheap, effective, and locally available alternative, acting both as a fertilizer and a soil improvement treatment. Urine biochar in combination with legume crop farming can be an important tool to increase food security and cropland diversity in areas with degraded soils, scarce organic resources, and inadequate water and chemical fertilizer supplies. Many of the families of migrant workers in the study districts in Udayapur already have considerable savings available for investment and are thus in a good position to develop the pea value chain to maximize the returns from their small plots of land and reduce their vulnerability to the impact of floods.

The beneficial effects of biochar have been recognized by many groups worldwide and were clear from the results of the farmers' trials. The Government of Nepal (GoN) has been emphasizing the promotion of organic farming. The National Agriculture Policy 2061 (2004 CE) emphasizes promotion of organic farming with the support of organic certification. The Agriculture Development Strategy (ADS) document includes complementary measures to improve productivity and fertilizer use efficiency. Biochar-based organic fertilizer can play an important role in sustainable organic production and, at a supplementary or complementary level, can help sustain soil fertility and minimize the use of inorganic fertilizers while maintaining productivity $[2,4,21]$.

The analysis of the pea value chain in Udayapur showed that at present villagers sell peas to wholesalers at a low margin. Selling shelled peas directly to wholesalers has no benefit, and can even be a loss. Sale of green peas has almost equal benefits and profits at the three levels from village traders to wholesalers and retailers. Selling seeds to wholesalers is more profitable than selling green peas or shelled peas but the administration is considerably more complicated. Farmers could increase their margin from 10 to $33 \%$ by selling pea pods directly to Kathmandu wholesalers, and to $44 \%$ by selling direct to Kathmandu supermarkets. For this they need to organize themselves into an association which can replace the various intermediaries currently involved. Other possibilities such as direct sale to consumers and packing or canning dried peas should also be explored.

\section{Future Directions}

Two types of recommendation can be drawn from the research; recommendations for actions and policies for the whole country and recommendations for introducing the pea value chain approach in the study districts in Udayapur.

(a) Countrywide recommendations

1. Promotion of biochar-based organic fertilizer should 
be made a priority in Nepal to help meet the government target of increasing organic matter content in soil from 1 to $4 \%$ over the next 20 years.

2. The introduction of legume crops with biochar-based organic fertilizer such as peas is an important approach for achieving the government's goal. Urinebiochar fertilizer with pea farming can complement government plans and policies. The district agriculture development offices are mandated to supply inputs (seeds and fertilizer) in their respective districts. This can be a leverage point for development of the urine-biochar based pea value chain. Government interventions should focus on reducing the use of chemical fertilizers and replacing them with urine-biochar based organic fertilizer.

3. Extension on best practices and demonstrations involving private sector suppliers and manufacturers of biochar is needed to further improve agricultural productivity.

4. Establishment of commercial bio-fertilizer production enterprises based on municipal biomass and agro processing waste should be facilitated.

(b) Recommendations for the pea value chain in Udayapur

1. The opportunities for linking smallholder farmers in Udayapur to other major markets in Nepal (Biratnagar, Janakpur, Narayangad, Pokhara, Kathmandu) and not only the nearest market (Gaighat) for sale of peas should be investigated.

2. Farmers should organize into producer groups or associations that can access larger markets.

3. Opportunities should also be explored for targeting key institutions with processed pea products (such as frozen peas) and for seed production. NGOs and others can provide key linkages for farmers to access these markets, including relevant training on markets.

4. Migrant workers' family groups in all six VDCs have established savings mechanisms and are linked to big cooperative institutions (Subha Laxmi and Small Farmers' Cooperative Bank Ltd). The finance available should be invested in the development of the pea value chain.

5. Feedstock for making biochar is available locally (Eupatorium and crop residues) and biochar making needs to be scaled up.

6. The government policy support system should help promote the pea value chain in the region to provide opportunities for smallholder farmers.

\section{References}

[1] MOAD, 2015. Agriculture Development Strategy of Nepal. Ministry of Agriculture Development, Singha Durbar, Kathmandu (Page 104).

[2] Schmidt, H., Pandit, B., Martinsen, V., Cornelissen, G., Conte, P., Kammann, C., 2015. Fourfold Increase in Pumpkin Yield in Response to Low-Dosage Root Zone Application of UrineEnhanced Biochar to a Fertile Tropical Soil. Agriculture 5,
$723-741$.

[3] Biederman, L. A., Harpole, W. S., 2013. Biochar and its effects on plant productivity and nutrient cycling: a metaanalysis. GCB Bioenergy 5, 202-214.

[4] Cornelissen, G., Pandit, N. R., Taylor, P., Pandit, B. H., Sparrevik, M., Schmidt, H. P., 2016. Emissions and Char Quality of Flame-Curtain "Kon Tiki” Kilns for Farmer-Scale Charcoal/Biochar Production. PLoS One 11, e0154617.

[5] Hoermann, B; Choudhary, D; Choudhury, D; Kollmair, M (2010) Integrated value chain development as a tool for poverty alleviation in rural mountain areas: An analytical and strategic framework. Kathmandu: ICIMOD

[6] Joshi, S. R.; Rasul, G.; Shrestha, A. J. (2016) Pro-poor and Climate Resilient Value Chain Development: Operational Guidelines for the Hindu Kush Himalayas : ICIMOD Working Paper 2016/1. Kathmandu, Nepal: ICIMOD

[7] Gathorne-Hardy, A., Knight, J., Woods, J., 2009. Biochar as a soil amendment positively interacts with nitrogen fertiliser to improve barley yields in the UK. IOP Conf. Ser. Earth Environ. Sci. 6, 372052.

[8] Steiner, C., Teixeira, W. G., Lehmann, J., Nehls, T., de Macêdo, J. L. V., Blum, W. E. H., Zech, W., 2007. Long term effects of manure, charcoal and mineral fertilization on crop production and fertility on a highly weathered Central Amazonian upland soil. Plant Soil 291, 275-290. http://www.biochar-international.org/biochar.

[9] Schmidt, HP., Kammann, C., Niggli, C., Evangelou, MWH. Mackie, K. a., Abiven, S., 2014. Biochar and biochar-compost as soil amendments to a vineyard soil: Influences on plant growth, nutrient uptake, plant health and grape quality. Agric. Ecosyst. Environ. 1 -7.

[10] Link- http://www.biochar-international.org

[11] Riisgaard, L., S. Bolwig, S. Ponte, A. du Toit, N. Halberg., F. Matose. 2010. Integrating poverty and environmental concerns into value-chain analysis: A strategic framework and practical guide. Dev. Policy Rev. 28(2):195-216.

[12] ICRAF, 2014. Commodity Selection Matrix, World Agroforestry Center, Bagor, Indonesia.

[13] Schmidt HP, Taylor P (2014): Kon-Tiki flame cap pyrolysis for the democratization of biochar production, the BiocharJournal 2014, Arbaz, Switzerland, pp 14 -24, www.biocharjournal.org/en/ct/39.

[14] Link- http://opensourceecology.org/wiki/Kon-Tiki_Kiln.

[15] Babatola LA, Ojo DO and Lawal IO (2008). Influence of Storage Conditions on Quality and Shelf Life of Stored Peas. Journal of Biological Sciences, 8(2): 446-450.

[16] Jokanovic, MR, Jokanovic D, Tepic AN (2006). Suitability of some green pea (Pisum sativum L.) varieties for processing. Acta Periodica Technologica 2006, 37: 13-20.

[17] Sidhu, RS., Sidhu, MS and Singh, JM. 2011. Marketing Efficiency of Green Peas under Different Supply Chains in Punjab. Agricultural Economics Research Review, 24: 267-273.

[18] Singla, R., Chahal, SS. and Kataria, P. 2006. Economics of production of green peas (Pisum sativum) in Punjab. Agricultural Economics Research review. 19: 237-250. http://faostat3.fao.org/download/Q/QC/E 
[19] Martinsen, V., Mulder, J., Shitumbanuma, V., Sparrevik, M., Børresen, T., Cornelissen, G., 2014. Farmer-led maize biochar trials: Effect on crop yield and soil nutrients under conservation farming. J. Plant Nutr.

[20] Kammann, C. I., Schmidt, H. P., Messerschmidt, N., Linsel, S., Steffens, D., Müller, C., Koyro, H.-W., Conte, P., Joseph,
S., 2015. Plant growth improvement mediated by nitrate capture in co-composted biochar. Scientific Reports 5: 11080.

[21] Jeffery, S., Abalos, D., Spokas, K. A., Verheijen, G. A., 2015. Biochara effects on crop yield, in: Lehmann, J., Joseph, S. (Eds.), Biochar for Environmental Management. Earthscan, London, pp. $301-326$. 